\title{
Infant Industries Protectionism: The Case of Automobile Industry in Malaysia
}

\author{
Dalia Ibrahim Mustafa \\ Department of Islamic Banking, School of Shari'a (Islamic Studies), the University of Jordan, Amman, Jordan
}

Email address:

Dalia.mustafa@ju.edu.jo

\section{To cite this article:}

Dalia Ibrahim Mustafa. Infant Industries Protectionism: The Case of Automobile Industry in Malaysia. International Journal of Business and Economics Research. Vol. 9, No. 2, 2020, pp. 68-72. doi: 10.11648/j.ijber.20200902.12

Received: November 22, 2019; Accepted: February 24, 2020; Published: February 28, 2020

\begin{abstract}
Having a competitive advantage in infant industry is a vital factor for a country to be efficient in protecting it since usually those infant industries lack the economic scales needed to survive in the market. The protectionism started in eighteenth century in USA as a suggestion for the government to promote the economy. The paper covers several tools are used such as; tariffs and tariff rebates, quotas, governmental subsidies and import-substitution industrialization (ISI). Theoretically it was proved the possibility of achieving the desired results. Then the paper illustrated Malaysia faced several failed stories of providing protection of its automobile infant industry; Proton and Perdua automobile companies were investigated. The results showed that those policies and tools used became a burden on the government budget without being able to compete internationally after decades of protection. Many reasons behind this shock fact such as the tendency of being secure which yield to conceal the truth of being prepared to face the global market competition without protection shields from the government. Also, those countries provided protectionism slowed down economically which led to more obstacles for the protected infant industries to be competitive internationally. Even the efforts of connecting the infant industry with strategic foreign partner have failed miserably in Malaysia. Hence as a recommendations for future attempts of protecting infant industries; the time span of protection should be predetermined and be flexible to adjust simultaneously. In addition, the government should monitor the protected firms to let them disclose the truth. Also, there should be a mix of protection tools used to achieve the optimal goal which is not only to protect the infant domestic industries but to promote them and be internationally competitive and that result can be reflected in growth of the economy.
\end{abstract}

Keywords: Infant Industry, Protectionism, Malaysia, Tariffs, and Quotas

\section{Introduction}

The governments tend to protect its infant industries from foreign competition. Usually infant industries lack economic scale that other mature and foreign firms in the same industry may have [4]. The main incentives behind protectionism are raising the employment rate and adding value to the economy of the country.

Expanding the market share of these domestic industries requires more workers as production input, and over time those industries may gain competitive advantage and provide the employees and workers with new skills and qualifications that may leverage them over foreign expertise. Also, the potential of enhancing economic growth is not an incidental issue; the country which applies the protectionism of infant industry is intending to enrich the social welfare and life standards $[12,20]$.

Protectionism may be applied by creating a barrier using different protection tools such as tariff, quotas, and governmental subsidies, among other tools [4, 5, 8, 13]. Protecting infant industries do not help the economy of a country unless it helps the industry to be competitive in the long-run [12].

One of the main issues that should be discussed regarding infant industry is the efficient use of the country's resources; therefore the protected infant industry should assist in building a comparative advantage for the country. Although, some infant industries do not have competitive advantage, they are politically important for the country and they are expected to gain national welfare in the future $[15,22]$.

Unfortunately, the successful stories of protecting infant industries are very rare. The policies used for infant 
industries did not yield in economic development, because of the distortion cost resulted which lowers the social welfare and Malaysian automobile industry is one of those examples $[4,22]$.

The remainder of this paper is divided as follows; section 2 provides the literature review which highlights the main reasons behind the failure of the protection schemes. Then section 3 introduces the main tools used in protecting the infant industry. The following is section 4 which investigates the Malaysian automobile infant industry; it illustrates the distortion of various tools of protection that were used there through several decades starting in 1980s. And finally section 5 summaries the paper through outlining the conclusion and providing some suggestions for future authors.

\section{Literature Review}

The argument of protectionism of infant industries was revealed by Alexander Hamilton ${ }^{1}$ in 1791 , his attempt is considered the first proposal provided in order to promote the protectionism. He provided propositions of governmental policies in USA to ensure the development of the economy which he claimed that it would be achieved through protecting the infant industries through subsidizing the domestic manufacturers, imposing tariffs [11].

Even Adam Smith admitted in his famous book "The Wealth of Nations, 1776" the possibility of supporting the manufacturing industry and raise the custom duty on the concurrent products, and to work along the government policies to initiate a comparative advantage of the infant industry to be cheaper than the imported goods of the same type.

Since USA went through difficult times back then, it has to seek protection for its manufacturing industry; however that does not mean rejecting the free exchange agreements between USA and other countries. USA in $18^{\text {th }}$ century was a head in agriculture rather than manufacturing industry, thus, it has to balance to be efficient enough in both industries [11].

The German economist Friedrich List followed Hamilton emphasizing the importance of protectionism in the presence of British industry. List developed what is known as "National system"; heupholded a free trade for the domestic goods and to impose high rates of tariffs on the exports of concurrent products. He also supported his point of view through highlighting the national benefits gained from receiving the tariffs and see them as "investment in a nation's future productivity" [7].

Moreover, politicians, in developing countries, find it politically important to protect some new industries that will enhance the welfare of the society in the future [9]. Thus, those industries would not establish without the intervention of the government in the initial period. Moreover, it is important to consider those infant industries before sitting the trade policy as entering WTO or GATT which open the local market internationally [23].

Bastable (1921) mentioned that the external benefits of protecting infant industry should exceed the cost of the protection, otherwise the country will suffer from welfare loss. Therefore, Mill (1848) noted that the protection should persist till the industry become self-sustained and globally competitive $^{2}$. The dilemma is determining the time period needed for the infant industry protection, because the firms of the infant industry will keep claiming they need more time to be able to compete internationally, on the other hand, if the government leave those industries earlier than it should be it would be costly to the domestic community.

Thus, there are many shortcomings for protectionism of infant industries that were covered in the previous literature and one of them is protection may attract foreign direct investments in import competing sectors, and not to sectors of exported goods which leads to distortion between those industries in one economy [6].

Therefore, previous studies claimed the importance of costs and benefits to be taken into account not only benefits [19], the externalities may remove the mist and pinpoint the feasibility of the protectionism. A set of procedures were suggested as a solution of this dilemma which are [21]; specifying an import quota, declaring the time span of protection, determining the externalities (social benefits) of protectionism mechanisms, and offering incentives for the firms to speak the truth regarding its readiness to dispense the protection. The protection should be passed up when the marginal cost of production equal zero.

The gap between the marginal cost between foreign production and the domestic one leads the government loses the appetite to provide the appropriate protection. The government however should notify the social cost of imports; those costs should be lesser in comparison of subsidizing the domestic production over time. Two examples were proposed for determining the time span of protection [21]; firstly they assumed the information regarding decision making is known publicly, they suggested the protection should be granted as long as the domestic production cost remains high. Secondly; they assumed the information is known privately -which is more realistic- the import quota to be increased gradually while the subsidy granted for the domestic firms is decreased.

Some of the researchers argue that because of capital market failure and poorly working laws, new industries are not allowed to take loans, thus the infant industries fail. This argument is actually built on the assumption of information asymmetry between entrepreneurs, government and market. When two types of revenue sources were examined -which are intra-industry redistribution, and outside funding-the conclusion was that output, prices, and welfare are independent of the funding method [20]. Moreover, the protection affects savings which then slows down the rate of growth in the economy [10].

1 Alexander Hamilton proposed this argument as part of a speech to the House of 


\section{Tools Used for Protectionism}

Several tools and policies were used worldwide to support infant industries since Hamilton first proposal of protectionism in USA, the following is among the most used ones:

Tariffs are tax on exports imposed to safeguard the domestic producers. Import-substitution industrialization (ISI) is an approach that is used for several purposes; one of them is to protect infant industry. This approach was prevailed in 1980s; its aim was to improve those industries by limiting competition of imports through imposing high rates of tariff on those imports. During the period (18161945) USA had the highest rates of tariff worldwide [5]. However, several studies showed that tariff would not be the optimal protection tool to help an infant industry. He clarified that if the government uses tariff, then tariff rates should decline to become zero when the human capital is accumulated through the knowledge and experiences. Hence, the producers gain in the period of protection. Moreover, Tariff negatively affects non-protected industries in the country by increasing the costs of their inputs which may discourage production of these industries.

Tariffs Rebates used frequently to smooth the entrance of exported inputs needed in the domestic infant industries. The export inputs might be at lower costs and better quality, therefore tariff rebates are considered as quality control tool.

Quotas are used to protect infant industries as well. However, Generally speaking, the losses of quotas may exceed those resulted from tariff [8]. Another form of quotas is Rent-seeking which might be resulted from high effective rate of protection. It also can be used through organizing lobby [13]. The cost of rent -seeking is higher than the cost resulted from quota. Therefore, the use of quota tools is not allowed under WTO laws.

Governmental Subsidies are a financial aid to a specific domestic sector to support its producers against concurrent imported goods and services. It can be determined as fixed amount per unit of production, or as a percentage of total production value. During the period of (1721-1848) Britain followed aggressive policies to protect infant industries through subsidizing the manufacturers and imposing high rates tariffs on exported goods up to late of 1820s. Similarly, USA used subsidies in the "catch-up position" in order to not only to protect but to promote its infant industries [4].

\section{The Malaysian Automobile}

In 1980s, Malaysia started targeting the industry of automobile among other types of heavy and resource-based industries in the second round of Import Substitution Industrialization (ISI) ${ }^{3}$. Proton project was attempted by Tun Dr. Mahathir Mohammad the Prime minister of Malaysia [22]. The PM simulated the Japanease economic development model, and to strengthen the launch of Proton

3Ministry of Trade, Malaysia (2018) he chose Mitsubishi Motors as a partner of this joint venture project. Two years later Proton was in the Malaysian streets strolling around [20]. The Malaysian government raised the tariffs of the foreign vehicles to expand the Proton's market share in Malaysia, and also government vehicles were imposed to be Proton.

Malaysian government continued protecting the automobile industry for several decades attempting to strengthen the Automobile industry, pursing to increase the employment rate and to enhance the economic growth which is measured by change rate of Gross Domestic Product (GDP).

Therefore, the heavy-based industry was considered beneficial for the national welfare, the Malaysian government found it politically and socially important to establish automobile industry. In 2006, the Minister of tradein Malaysia announced the new National Automative Policy (NAP), which consists seven measures: "(1) Streamlining of excise duty structure to promote greater transparency in car pricing. (2) Regular publishing of the values of imports cars to avoid tax underdeclaration. (3) Regular the ASEAN CEPT import duty to $5 \%$ for qualifying vehicles. (4) Grants from the industrial Adjustment Fund to car manufacturers with competitiveness and value-added. (5) Temporary freezing new manufacturing licenses until the current production over capacity is overcome. (6) Phasing out the current system of Approved Permits (AP) by December 31, 2010. (7) Implementing Vehicle Type Approval processes and procedures"4.

Proton was the first automobile company in Malaysia, which was protected through massive subsidies to create economies of scale that was well-established automobile exporters, have. Proton automobiles, such as Saga, were sold at very low prices relative to the prices of imported automobiles, with reduction in excise duty to $50 \%$. Direct grants (subsidies) are used to promote R\&D capacity such as Industry R\&D Grant Scheme ${ }^{5}$. Moreover, the Malaysian government tried to enhance $R \& D$ by linking research and consultancy firms with public universities to encourage university-industry collaboration in $R \& \mathrm{D}^{6}$. Yet, the industry could not be developed enough to compete worldwide.

Malaysian government also used Quota to restrict the quantities of imports during a specific period. The purpose was obvious which is to push consumers to purchase the locally manufactured cars such as Saga. Interestingly, people moved from purchasing the foreign manufacturing automobiles which became very limited in quantity and expensive relatively to their level of income. While the government of Malaysia tried to attract foreign direct investments (FDI), the government prohibits the foreign companies -which are established in Malaysia- to sell its production locally; instead all production must be exported outside.

4Ministry of Trade, Malaysia (2006)

5Ministry of Trade, Malaysia (2006).

6 Toh Kin Woon (Former State Minister of Planning Education \& HR development in Penang Malaysia) 
In 2018, DatoMustapa the minister of MITI (ministry of international Trade and Industry claimed that "the growth of the automotive industry has created new career opportunities for Malaysians."'The statistics showed in 2018 that 5\% of total employment in Malaysia workedin automobile industry, while 160 billion MYR was the contribution of Malaysian automobile industry (4\% of GDP) [3]. However, the protectionism in this infant industry failed.

Without leveraging the technological aspect of Proton, it was almost impossible to have competitive advantage [22]. Despite the fact that protectionist policies was suggested to be 10-15 years isbeneficial in supporting the automobile industry in Malaysia, then the industry should be able to compete internationally [3], trade barriers were imposed in the mid of 1980s up to now. More than thirty years of protection and the industry yet is unable to compete internationally which confirm what Bastable proposed as condition for successful protection policy.

Nowadays the Malaysian automobile industry are not considered infant anymore, it is in its mature phase of its business cycle, and the only international entity that can impose some pressure over Malaysia to liberalize trade is ASEAN. It is worth noting that Malaysian government was awake of the benefits gained from protecting the automobile industry such as the tariff revenue which is estimated to be around 20 billion MYR in 2017, and risking more than 730 thousand jobs of Malaysians working in that industry [3].

Malaysian government imposed tariff which was approximately $8.1 \%$ in 2005 . Although later Malaysia started to reduce tariff on foreign imported automobile, it imposed a high excise duty bringing down the rates from $90 \%-250 \%$ to $80 \%-200 \%$. In addition, by imposing tariff a consumption distortion would result and there is even no guarantee that domestic production would increase [18]. And that was the case, $97.6 \%$ of automobile unit sales in Malaysia in 2017 is dominated by foreign brands ( 21 brands $)^{7}$.

Moreover, the welfare loss in 2017 was 9.37 billion MYR, in comparison to the revenues generated by the two domestic automobile firms (Proton and Perdua) is 12 billion MYR. On other hand, the total value of those two firms (total assets in their financial statements) is around 9.8 billion MYR, thus, it is almost as the amount of welfare loss. Now the one can imagine the harm of the protection methods such as tariffs affected the local community in Malaysia, especially when the one recall it started at the mid of 1980s. Also hypothetically, eliminating the tariffs over the foreign brands would result in lower prices than the price of the domestic brands (Proton and Perdua), which may result in increasing the demand overall.

Ironically, in 1990s, a new automobile industry was established, Perodua. The government did not offer protection, or at least not as it providedto Proton. Thus, Perodua found itself in the middle of the "real" world facing local and international competitors, locally it has to compete

7 A detailed table of the foreign brands and their market share percentages can be found in (Borer and Chua, 2018)
Proton which was protected and gained experience and knowledge in more than 10 years. However, Perodua developed more efficient system. It started to strengthen itself to be able to survive in the market with lack of protection; over $40 \%$ of Perdua's shares owned by Toyota, which yield to a high degree of cooperation with one of the most brands of automobile firms. After almost 20 years of protecting Proton, the government started to lose hope in this industry and eliminate the protection tools gradually!

Therefore, among several recommendations provided for Malaysian automobile are the following; gradual reduction of tariffs on the imported automobiles. Also, during this period of transition from protecting the infant industry to leaving it to compete internationally, the tariffs revenues should be used to rehabilitate the employees to move to other industries. Moreover, strategic partnerships with international manufacturers should be initiated and strengthened [4]. Also, Export-Oriented Industrialization (EOI) is considered as an alternative strategy. It focuses on international trade, through finding another country with comparative advantage to export goods with [15].

\section{Conclusion}

This paper presents an empirical example of the failure of infant industry protectionism. The infant industry argument is valid, theoretically. Several tools might be used for protectionism of infant industries such as; tariffs and tariff rebates, Import-substitution Industrialization (ISI), quotas, and governmental subsidies. Alexandar Hamilton was the first attempt to set protection policies and procedures in USA in 1791.

However in the real world protecting those industries is not helping them to grow up, instead they tend to feel secure and start to hide the truth of being ready to face the global market competition without protection shields from the government. Therefore, it was suggested to determine the appropriate time span for the protection regime that it should not be too long that would throw a heavy burden on the shoulders of the country with loads of costs, and not too short that might lose its purpose.

Also, the economic growth in the countries which adopted protectionism policies slowed down than the countries not adopting them. Furthermore, those protected industries had not become competitive worldwide.

Unfortunately Proton, which is a Malaysian automobile company, could not achieve the planned objectives of infant industry protection; it did not become competitive worldwide nor had a social value-added, instead it turned to be a burden on the government budget. This outcome can be explained that Proton Company lived in a very cozy environment. This artificial comfortable environment that was created by those different tools of protection actually worsens the efficiency of the industry and lowers its ability to compete in the global market. Therefore, when Perodua was launched it was intended to offer protection; instead, a strategic investor was introduced with $40 \%$ ownership that was Toyota. 
Hence as a result of the discussion above, the time span of protection should be predetermined and be flexible to adjust simultaneously. In addition, the government should monitor the protected firms to let them reveal the truth. Moreover, there should be a mix of protection tools used to achieve the optimal goal which is not only to protect the infant domestic industries but to promote them and be internationally competitive which should be reflected in growth of the economy.

For future research I believe it is helpful to compare the different policies used for protectionism in developing countries and compare it with the requirements of the international agreements that those countries involved in. It is also useful to apply the model suggested by (Ravikumar, 2017) to design the optimal protection strategy.

\section{References}

[1] Alexander Hamilton, Report on the Subject of Manufactures, To the Speaker of the House of Representatives, (Philadelphia: December 5, 1791). Accessed 24th September 2018, https://founders.archives.gov/documents/Hamilton/01-10-020001-0007.

[2] Ali, Salamat. (2011). "Why have most cases of infant-industry protection failed to generate benefits in terms of economic development?". London School of Economics and Political Science. Working paper.

[3] Baldwin, R. E. (1969). The case against infant-industry tariff protection. Journal of Political Economy, 77 (3), 295-305.

[4] Borer D. and B. Chua. (2018). How costly is the Malaysian car? Estimations of Welfare Costs of Protecting the Vehicle Industry of Malaysia. Conference paper. 2018 International Conference on Technology and Humanities IcoTECH 2018 in Cooperation with KDU University College Penang November 17-18, 2018.

[5] Chang, H. J. (2003). Kicking away the ladder: Infant industry promotion in historical perspective. Oxford Development Studies, $\quad 31 \quad$ (1), 21-32. https://www.tandfonline.com/doi/pdf/10.1080/1360081032000 047168? needAccess $=$ true

[6] Cordon W. (2002). "Trade Policy and Economic Welfare". Second Edition. Clarendon Press. Oxford. New York. United States of America.

[7] Encyclopædia Britannica: Friedrich List.

[8] Feenstra, R. C. and Taylor, A. M. (2002). International Economics. 2nd international ed. Houndmills, Basingstoke, Hampshire.
[9] Grossman G. and E. Helpman (1994). "Protection for Sale". American Economic Review. Vol 84. Pp: 833- 850.

[10] Hausman R. and D. Rodrick (2003). "Economic Development as Self-Discovery". Journal of Development Economics. Vol. 72. Pp: 603-633.

[11] Kicsi, R., \& Buta, S. (2010). Protectionism and "Infant" Industries. Theoretical Approaches. The Annals of "Dunarea de Jos" University of Galati. Fascicle I - 2010. Economics and Applied Informatics.

[12] Krueger, A. O. and Tuncer, B. (1982). 'An Empirical Test of the Infant Industry Argument.' The American Economic Review 72 (5): 1142-1152.

[13] Magee, C. S. (2011). Why are Trade Barriers so low? Economic Affairs, 31 (3), 12-17.

[14] Mill, J. S. (1848). Principles of Political Economy in Collected Works, vols II-III.

[15] Milward, B. (2019). International Trade and Sustainable Development: Economic, Historical and Moral Arguments for Asymmetric Global Trade. Routledge.

[16] Ministry and International Trade and Industry, (2018). (2018). https://www.miti.gov.my/miti/resources/Media\%20Release/M edia_Release_-

Automotive_Outlook_2018_\%E2\%80\%93_Holistic_Industr y_Growth_Continues_As_National_Automotive_Policy_2014 _(NAP2014)_Enters_Fifth_Year.pdf

[17] Ministry of Trade, Malaysia. (2006)

[18] Pack, H. and Saggi, K. (2006). 'Is There a Case for Industrial Policy? A Critical Survey.' The World Bank Research Observer 21 (2): 267-297.

[19] Panagariya, A. (2011). A re-examination of the infant industry argument for protection. Margin: The Journal of Applied Economic Research, 5 (1), 7-30.

[20] Petkov, Vladimir P. (2007). Infant Firm Subsidization in Industries with Dynamic Structure. J Ind Compet Trade.

[21] Ravikumar, B., Riezman, R., \& Zhang, Y. (2018). Optimal Infant Industry Protection. In 2018 Meeting Papers (No. 1016). Society for Economic Dynamics.

[22] Tong, J. T., Terpstra, R. H., \& Lim, N. C. (2012). Proton: Its rise, Fall, and Future Prospects. Asian Case Research Journal, 16 (02), 347-377.

[23] Xu B. (2006). "Infant Industry and Political Economy of Trade Protection". Pacific Economic Review. Vol. 11, No. 3. Pp: 363- 378. 